\title{
Drinking water quality evaluation of hand pumping wells using water quality index and standard algal toxicity testing in Mansoura and Talkha cities, Egypt
}

\author{
Marriam M. Ismail ${ }^{1}$ *
}

\author{
Ahmed M. El-Naggar ${ }^{1}$ \\ Ahmed E. Hagras
}

\author{
Mai I. El-Gammal
}

${ }^{1}$ Zoology Department, Faculty of Science, University of Mansoura, Egypt

${ }^{2}$ Department of Environmental Sciences, Faculty of Science, Damietta University, Egypt.

*Corresponding author: marriam.m.ismail@gmail.com*, naggar2100@yahoo.com, prof.elwazer@gmail.com

"ORCID ID: https://orcid.org/0000-0003-1839-0572*

Received 9/8/2020, Accepted 19/10/2020, Published Online First 30/4/2021, Published 1/12/2021

This work is licensed under a Creative Commons Attribution 4.0 International License.

\begin{abstract}
:
Six house-hold Abyssinian pumps distributed in different villages of Mansoura (Mans-I, Mans-II and Mans-III) and Talkha (Talk-I, Talk-II and Talk-III) cities, Egypt, have been selected for regular seasonal water quality assessment during 2017. Water samples have been collected within the mid-periods of four seasons Standard assessment tools were employed for the integrated water quality assessment including Water Quality Index (WQI) and ISO standard algal toxicity test. WQI displayed remarkable local and seasonal variations with excellent $(\geq 90)$ and good $(70$ - 89) only recorded for water samples collected from Mans-I pump located in sparsely populated area and far 50 meters only from the eastern (Damietta) branch of Nile River. WQI of other pumps located in densely populated areas and far kilometers from the Nile branch indicated either medium (50-69) or bad (25-49) quality depending on sampling season and sampling site location. All water samples collected from the pump Mans-I were non toxic without any inhibitory effects on the growth of the standard test alga Pseudokirchneriella subcapitata. Water samples from all other pumps, however, showed obvious toxic effects on test algae growth with varying $\mathrm{EC}_{50}$ values ranged between $15.8 \%$ and $83 \%$, depending on water sample and the sampling season. Concisely, all water samples collected from Mans-I pump were health safe with acceptable drinking water guidelines while samples collected from other pumps can impose great human health risks if used for drinking.
\end{abstract}

Keywords: Abyssinian pumps, Algal bioassays, Drinking water, Tube-well aquifer, Water Quality Index

\section{Introduction:}

It has become evident that water scarcity and declining access to drinking water of acceptable and health safe quality represent acute global problems prevailing in arid and semi-arid countries, including Egypt.

Water quality is a term used to characterize the physico-chemical, and biological properties for its suitability for a specific use or purpose (1). Water Quality Index (WQI) is considered the most valuable method for accurate assessment of water quality. The index was developed, revised, and approved by the National Science Foundation (NSF) of United States (2).

Calculation of NSF- WQI primarily relies on nine related water properties including dissolved oxygen, fecal coliform, $\mathrm{pH}$, biochemical oxygen demand, temperature shift, total phosphate, nitrates, turbidity and total dissolved salts. The weight of each parameter is based on well-defined criteria and shows the importance and effect of the parameter on the index value WQI allows direct comparison between sampling sites and simplifies a complex dataset to provide easily understood and accessible information (3). Values of WQI range from 0.0 to 100 , denoting the worst and the best water quality conditions, respectively (2).

The green microalga Pseudokirchneriella subcapitata has been approved as a standard test organism for water quality monitoring and toxicity assessment (4). This standard test microalga maintains very sensitive response to narrow changes in quality of the tested solution(s) with marked growth inhibition and stimulation in response to toxic and non-toxic tested solutions, respectively. 
This is the premise upon which the usefulness and the importance of standard algal bioassays are based (5). A wealth of publications (e.g. 5, 6) highlighted the importance of using standard algal biotests for toxicity assessment and evaluation of water quality

It has become evident that groundwater is a vital supply of drinking water supply worldwide. In Egypt, the annual groundwater supply is about 20.65 billion $\mathrm{m}^{3}$ year $^{-1}$ and thus contributing by about $28 \%$ of available water resource in Egypt (7). This indicates the vital importance of groundwater for different multipurpose uses of water in Egypt.

In Egypt, the hand pumps prevail in rural areas as asource of multiuse underground water (8, 9). In general, underground drinking water in Delta region of Egypt can be pumped at depths ranged between 20 and 40 deeps from the underground sand layer.

Abdel-Shafy and Kamel (10) reviewed the groundwater in Egypt with special emphasis on resources, location, amount, contamination, protection and renewal. They reported that the quality of portable groundwater in the Nile delta has been threatened by chemical and microbiological pollution through various complicated routes. Domestic wastewater from septic tanks is a significant source of pathogenic bacteria and groundwater organic contamination $(11,12,13)$ Detection of bacterial markers in water samples is evidence of pathogenic species that are likely to cause waterborne fatal diseases (14)

Based on facts mentioned in the preceding paragraphs, it is a must to carry out regular water quality monitory of hand pump waters to assess its health safety and hazard to the ultimate consumers including man. The present studyfocused on an integrated assessment of water quality of six selected household Abyssinian pumps based on water quality index (WQI) and ISO standard algal biotest for toxicity assessment. The specific object is to assess the quality of raw ground water, according to nationally and internationally accredited parameters, to draw any conclusion or recommendation on valid reasons.

\section{Materials and Methods:}

\section{Study area and sampling stations \\ 1. The study area}

Figure 1 shows the map of Egypt (A), where the geographical location and the area of Dakahlia Governorate are represented by a black block, from which an arrow points to the administrative map of Dakahlia Governorate (B). An orbit encircles Mansoura and Talkha, the cities (Merkez) from which water samples were collected from six households' Abyssinian pumps distributed in different villages. A Google earth map (C) illustrates the topographic locations of different sampling sites from which well (ground) water samples were seasonally collected.

\section{Sampling stations}

A total of six household Abyssinian pumps were selected for regular seasonal water sampling, three are located in different villages of Mansoura (MansI, Mans-II and Mans-III) Merkez (city) and three (Talk-I, Talk-II and Talk-III) located in different villages of Talkha city. Table 1, lists a host of a full descriptive data including the village name, the sampling site code, its coordinates, and its vertical straight line distance $(\mathrm{km})$ from the eastern (Damietta) branch of the River Nile. Important information about water uses from each sampling site in addition to other important additional remarks are also included in Table 1 . In all cases, the water was pumped from the underground aquifers at depths ranged between 20 and 30 meters as the owners of pumps indicate collected in $22^{\text {nd }}$ February), Spring (22 ${ }^{\text {nd }}$ April and $22^{\text {nd }}$ May), Summer (22 $2^{\text {nd }}$ July and $22^{\text {nd }}$ August $)$ and Autumn $\left(22^{\text {nd }}\right.$ October and $22^{\text {nd }}$ November.

Before sampling, the water pump was operated for three minutes to pump out water in order to wash out any contaminants from the pump mouth and to ensure that the collected water sample represent the underground well water. Samples for chemical analysis water were collected in large (4L volume) wide mouth HDPE (High Density Polyethylene) plastic bottles of food grade quality.

Samples for bacteriological analysis were collected in $500 \mathrm{ml}$ clean and sterilized sample Pyrex glass, provided by the ISO certified, Central Laboratory of Dakahlia Potable Water and Sanitary Drainage Company, MitKhamis, Mansoura, Egypt.

\section{Meteorology of the study area}

The climate of the study area is more or less dry and consists of four distinct seasons: summer, autumn, winter, and spring. Winter extends from $20^{\text {th }}$ of December to the $21^{\text {st }}$ of March. It is, relatively, the coldest season in Egypt with minimum day length and sunshine. The season also experiences some showers which are irregularly distributed during its period. The spring starts from $21^{\text {st }}$ of March and lasts till the $20^{\text {th }}$ of June. During spring, air temperature, humidity, day length and the duration of bright do increase to reach maximum levels in summer. Summer commences from $21^{\text {st }}$ June and continues till the $20^{\text {th }}$ of September. It is characterized by high atmospheric temperature, relative humidity, bright sunshine and longer days. The autumn season starts from $21^{\text {st }}$ September till $20^{\text {th }}$ of December. In this period the air temperature, 
duration of bright and day length decrease, also the sky gets cloudy sometimes.

\section{Field analyses}

Water temperature $(15: 2550-\mathrm{B})$ and $\mathrm{pH}(15: 4500-$

$\mathrm{H}^{+}$) were measured right at sampling stations using
HANNA waterproof portable $\mathrm{pH} /$ temperature meter - HI991001. At least three readings were taken, and an average was calculated.
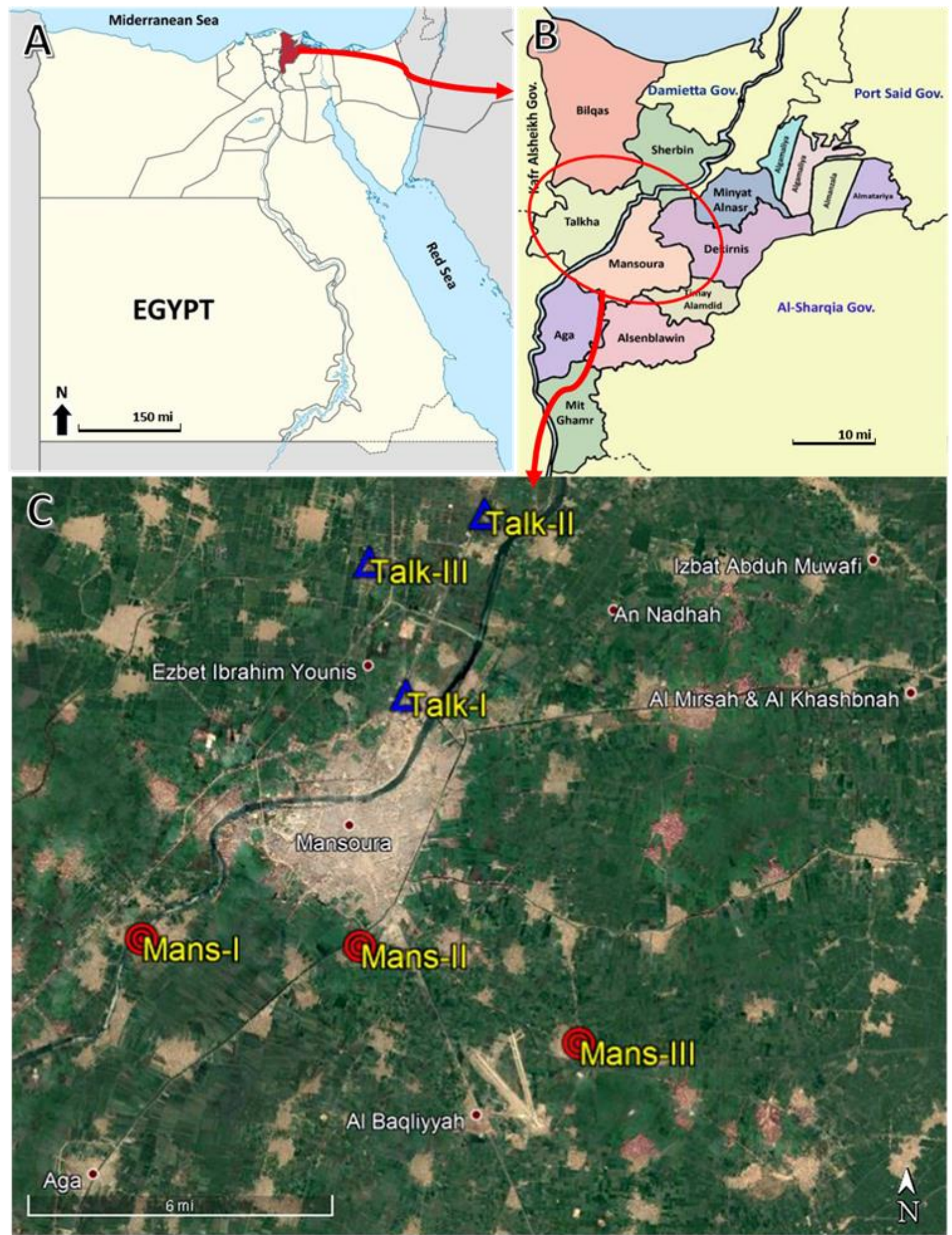

Figure 1. Map showing geographical locations of the sampling stations. A) Map of Egypt, B) Administrative map of Dalkahlia Governorate, and C) Google earth map showing the different sampling stations of Mansoura (Mans-I, II, \& III) represented by red circle (•) and Talkha (Talk-I, II, $\&$ III) represented by blue triangle $(\Delta)$. 
Table 1. Native names of sampling sites, their codes, coordinates and distances to Damietta (eastern) branch of the River Nile

\begin{tabular}{|c|c|c|c|c|}
\hline Site name & $\begin{array}{l}\text { Sampling } \\
\text { site code }\end{array}$ & Coordinates & $\begin{array}{l}\text { Distance }^{\mathbf{a}} \\
(\mathrm{Km})\end{array}$ & Supplementary notes and remarks \\
\hline $\begin{array}{l}\text { Kafr Ash } \\
\text { Shinhab, } \\
\text { Mansoura }\end{array}$ & Mans-I & $\begin{array}{l}31^{\circ} 0^{\prime} 29.30^{\prime \prime} \mathrm{N} \\
31^{\circ} 18^{\prime} 33.90^{\prime \prime} \mathrm{E}\end{array}$ & 0.05 & $\begin{array}{l}\text { itis located at the western edge of Kafr Ash Shinhab village. } \\
\text { Water is mainly used for drinking of humans and animals } \\
\text { and other domestic purposes. Water is pumped from } 30 \\
\text { meter deep }\end{array}$ \\
\hline $\begin{array}{l}\text { MinyatSan } \\
\text { dub, } \\
\text { Mansoura }\end{array}$ & Mans-II & $\begin{array}{l}31^{\circ} \\
0^{\prime} 22.00^{\prime \prime} \mathrm{N} \\
31^{\circ} 22^{\prime} 55.40^{\prime \prime} \mathrm{E}\end{array}$ & 9.801 & $\begin{array}{l}\text { This household pump is located in a densely populated area. } \\
\text { The water maintains a multiuse nature. Water may be used } \\
\text { for drinking in case of temporarily municipal water is cut- } \\
\text { off. Water is pumped from } 20 \text { meter deep }\end{array}$ \\
\hline $\begin{array}{l}\text { Tilbanah, } \\
\text { Mansoura }\end{array}$ & Mans-III & $\begin{array}{l}30^{\circ} 58^{\prime} 42.80^{\prime \prime} \mathrm{N} \\
31^{\circ} 27^{\prime} 17.00^{\prime \prime} \mathrm{E}\end{array}$ & 10.059 & $\begin{array}{l}\text { This pump is surrounded with a densely populated area. It } \\
\text { is situated at only } 30 \text { meters from a domestic and } \\
\text { agricultural wastewater drain The water is of a multiuse } \\
\text { nature but mainly used for laundry and drinking water for } \\
\text { household animals. Water may be used for drinking in case } \\
\text { of temporarily municipal water is cut-off. Water is pumped } \\
\text { from } 25 \text { meter deep }\end{array}$ \\
\hline $\begin{array}{l}\text { MitAntar, } \\
\text { Talkha }\end{array}$ & Talk-I & $\begin{array}{l}31^{\circ} \\
4^{\prime} 41.30^{\prime \prime} \mathrm{N} \\
31^{\circ} 23^{\prime} 51.30^{\prime \prime} \mathrm{E}\end{array}$ & 1.884 & $\begin{array}{l}\text { This household pump is located at the western edge of } \\
\text { MitAntar village. It is located at only } 20 \text {, meters from an } \\
\text { industrial wastewater drain The water is mainly used for } \\
\text { garden irrigating, drinking water for household animals and } \\
\text { cooling water for small-scale plastic grinding installations. } \\
\text { Water may also be used for drinking during municipal } \\
\text { water is cut-off. Water is pumped from } 25 \text { meter deep }\end{array}$ \\
\hline $\begin{array}{l}\text { Kafr at } \\
\text { Tawilah, } \\
\text { Talkha }\end{array}$ & Talk-II & $\begin{array}{l}31^{\circ} \\
7^{\prime} 50.40^{\prime \prime} \mathrm{N} \\
31^{\circ} 25^{\prime} 27.20^{\prime \prime} \mathrm{E}\end{array}$ & 2.136 & $\begin{array}{l}\text { This household pump is located in a densely populated area. } \\
\text { The water is pumped by an electric motor pump. The water } \\
\text { is mainly used for cooling system of a refrigerator for } \\
\text { storing vegetables and potato tubers. Water is also used for } \\
\text { drinking of household and farm animal but seldom for } \\
\text { humans as the owner confirmed. Water is pumped from } 30 \\
\text { meter deep }\end{array}$ \\
\hline $\begin{array}{l}\text { Al } \\
\text { Manyal, } \\
\text { Talkha }\end{array}$ & Talk-III & $\begin{array}{l}31^{\circ} \\
6^{\prime} 59.90^{\prime \prime} \mathrm{N}, \\
31^{\circ} 23^{\prime} 7.50^{\prime \prime} \mathrm{E}\end{array}$ & 7.968 & $\begin{array}{l}\text { This is a public pump located in a sparsely populated area. } \\
\text { The water is mainly used for cement brick industry and for } \\
\text { drinking of farm animals. From the same well a tube is } \\
\text { extending to a public bakery to prepare bread dough. Water } \\
\text { is pumped from } 30 \text { meter deep }\end{array}$ \\
\hline
\end{tabular}

\subsection{Laboratory analysis}

It must be highlighted that three separate aliquots water samples were used for the analyses of each chemical parameter. Chemical analyses were carried out according to their specific standard methods (15) including dissolved oxygen (15:4500$\mathrm{O}-\mathrm{B})$, biochemical oxygen demand (BOD) (15:5210-B), Nitrate-N (15:4500- $\left.\mathrm{NO}_{3}{ }^{-}-\mathrm{B}\right)$, phosphate-P (15:4500-P-D), turbidity (15:2320-B) and total dissolved salts (TDS) (15:2540-B). Simultaneous multi-element determination of the metals $\mathrm{Na}, \mathrm{Ba}, \mathrm{Pb}, \mathrm{Al}, \mathrm{Mn}, \mathrm{Cd}, \mathrm{Cr}, \mathrm{Cu}, \mathrm{Fe}, \mathrm{Zn}, \mathrm{Mo}$, $\mathrm{Sb}, \mathrm{As}$, and $\mathrm{Se}$ were done by Inductively Coupled Plasma-Mass Spectrometry (ICPMS) (21:3125-B). Analyses of heavy metals were carried out at Egyptian Atomic Authority (EAEA) laboratories, Cairo, Egypt.

\subsection{Bacteriological analysis}

Bacteriological analysis followed the membrane filter technique for thermo-tolerant fecal coliform bacteria (15:9222-D), Bacteriological analysis were carried out at Central Laboratory of Dakahlia Potable Water and Sanitary Drainage Company, MitKhamis, Mansoura, Egypt

\subsection{Drinking water guidelines}

Mean values of different physico-chemical and bacteriological parameters were matched against WHO (16) that is perfectly cope with Decree of Health Ministry (No. 458) Egyptian Standards for Drinking Water and Domestic Uses (issued in 2007 and written in Arabic Language)

\subsection{Water Quality Index (NSF-WQI)}

The American National Sanitation Foundation (NSF) proposed water quality index (2) was followed. Water quality index is a 100-point scale divided into multiple ranges representing the corresponding quality levels (Table 2). 
Table 2. Water quality index (WQI) range and classes

\begin{tabular}{ll}
\hline WQI range & WQI classes \\
\hline $90-100$ & Excellent \\
$70-90$ & Good \\
$50-70$ & Medium \\
$25-50$ & Bad \\
$0-25$ & Very Bad \\
\hline
\end{tabular}

2.8. Toxicity assessment of household pump water using standard algal growth bio-test

Toxicity assessment of water samples collected from different household water pumps was carried out according to ISO (4) with the standard test alga Pseudokirchneriella subcapitata, NIVA-CHL1, obtained from culture collection of the Norwegian Institute for Water Research, https://niva-cca.no/shop. The test procedures involves the addition of $1.0 \mathrm{ml}$ of each of the different 7 stock solutions of standard algal assay medium (AAM) (5) to 1.0 liter of pump water (tested solution) and distilled water (standard algal nutrient solution). Three replicate clean culture Pyrex flasks, each of $500 \mathrm{ml}$ capacity were used for each test solution. A volume of $100 \mathrm{ml}$ of different test solutions listed in Table 3 was added to each flask and all the test flasks were inoculated with a 5day-old culture of the test alga Pseudokirchneriella subcapitata NIVA-CHL1, giving $5 \times 10^{6}$ cells $\mathrm{L}^{-1}$ as initial algal density. Flasks were incubated for 4 days on a shaking table at $22 \pm 2{ }^{0} \mathrm{C}$ under continuous illumination of approximately $70 \mu \mathrm{E} \mathrm{m}$ ${ }^{2} \mathrm{~s}^{-1}$ provided with cool white fluorescent tubes. The control cultureswere only grown in standard AAM growth medium and were kept under the same growth conditions. The test duration was $96 \mathrm{hrs}$. At the end of the incubation period, the test cultures were shaken and equal volumes of control and test cultures were fixed with Lugol's solution (one drop/one $\mathrm{ml}$ culture). Algal cells were counted using standard haemocytometer Direct cell count (cells $\mathrm{L}^{-1}$ ) was to plot growth curves from which toxicity values $\left(\mathrm{EC}_{50}\right)$ were interpolated.

Table 3. Different volumetric proportions or concentrations $(v / v)$ of the tested solution of pump water

\begin{tabular}{|c|c|c|}
\hline Volumetric ratio $^{\mathrm{a}}$ & Volume $^{\mathrm{b}}(\mathrm{ml})$ & Volume $^{\mathbf{c}}(\mathrm{ml})$ \\
\hline 0.0 (Control, standard & 100 & 0.0 \\
\hline $6.25 \%$ & 93.75 & 6.25 \\
\hline $12.5 \%$ & 87.5 & 12.5 \\
\hline $25 \%$ & 75 & 25 \\
\hline $50 \%$ & 50 & 50 \\
\hline $100 \%$ (only household & 0.0 & 100 \\
\hline
\end{tabular}

${ }^{\mathrm{a}}$ Volume of pump water to the volume of the test solution

${ }^{\mathbf{b}}$ Volume of standard nutrient solution

${ }^{\mathrm{c}}$ Volumeof tested household pump water

\subsection{Calculation of $\mathbf{E C}_{50}$}

$\mathrm{EC}_{50}$ is median concentration that inhibits algal growth by $50 \%$ compared to control culture. The toxicity response parameter (algal cell count), calculated as a percentage of control (control = $100 \%$ ), was plotted against the corresponding pump water concentration logarithm. A curve with a thirdlevel polynomial was fitted to the points enabling $\mathrm{EC}_{50}$ to be calculated by straight line graphic interpolation (17)

\subsection{Statistical Analysis}

Dose response curves fitted to the points with a third level polynomial and other graphs with error bars were plotted with Origin 8.5 SR1, 2010, OriginLab Corporation, 1.0, Roundhouse Plaza, Northampton, MA 01060, USA, http://originlab.com

\section{Results:}

\subsection{Water Quality Index (WQI)}

The parameters for calculating water quality index (WQI) represent pertinent water quality parameters including dissolved oxygen (DO), fecal coliform, $\mathrm{pH}$, Biochemical Oxygen demand (BOD), temperature, phosphate-P, nitrate$\mathrm{N}$, turbidity and total dissolved salts (TDS). Mean seasonal variation of these water quality parameters during winter, spring, summer, and autumn 2017 are given in Tables 4, 5, 6, and 7, respectively.

Water $\mathrm{pH}$ ranged between 6.8 (Mans-I in summer, Table 6) and 8.4 (Mans-III, winter, Table 4) indicating that the $\mathrm{pH}$ of all water samples collected from different pumps during different seasons, fall in the range of drinking water guidelines (6.5-8.5). Similarly, Nitrate-N fluctuated between $1.8 \mathrm{mg} \mathrm{L}^{-1}$ (Mans-I, summer, Table 6) and 23.mg L $\mathrm{L}^{-1}$ (Talk-I, winter, Table 4) a result indicating that nitrate- $\mathrm{N}$ concentrations cope with drinking water guidelines (maximum of $45 \mathrm{mg} \mathrm{L}^{-1}$ )

Dissolved oxygen (DO) concentration of safe drinking water must be equal or higher than 5.0 $\mathrm{mg} \mathrm{L}^{-1}$. Accordingly, only water samples collected during this study from Mans-I, Mans-II, Mans-III, and Talk-I pumps cope with this specific water quality parameter. However, DO concentrations of water samples collected in all seasons from Talk-II and Talk-III pumps fell below the guideline level. In general, the lowest DO concentration $(1.4 \mathrm{mg} \mathrm{L}$ $\left.{ }^{1}\right)$ was recorded for the water samples collected from the pump Talk-II during summer (Table 6) and the highest one $\left(7.7 \mathrm{mg} \mathrm{L}^{-1}\right)$ was reported in winter for the water sample collected from Mans-I pump (Table 4).

Biochemical oxygen demand (BOD) is a pertinent assessment parameter of organic pollution of water. $\mathrm{BOD}_{5}$ values exhibited a wide range from 
$13.0 \mathrm{mg} \mathrm{L}^{-1}$ (Mans-I, winter, Table 4) to $437.5 \mathrm{mg} \mathrm{L}^{-1}$ (Talk-II, summer, Table 6). BOD $_{5}$ values of water samples collected from Mans-I, Mans-II and Mans-III fluctuated between $13.0 \mathrm{mg}$ $\mathrm{L}^{-1}$ and $25 \mathrm{mg} \mathrm{L}^{-1}$, while those of samples collected from Talk-I, Talk-II, and Talk-II fluctuated widely from $76 \mathrm{mg} \mathrm{L}^{-1}$ to $437.5 \mathrm{mg} \mathrm{L}^{-1}$ (Tables 4-7). This finding clearly indicates that biodegradable organic matter content of water samples collected from Talkha exceeds largely that of water samples collected from Mansoura

Like BOD, Phosphate-P lacks a drinking water guideline. During this study phosphate-P concentrations were relatively low and varied from $0.1 \mathrm{mg} \mathrm{L}^{-1}$ to $0.8 \mathrm{mg} \mathrm{L}^{-1}$ (Tables 4-7).

Water samples with turbidity exceeding 1.0 NTU are not acceptable for drinking. Water turbidity fluctuated widely between 0.5 NTU (Mans-I, autumn, Table 7) and 49.1 NTU (Talk-II, summer, Table 6). It is relevant to highlight that the turbidity of water samples collected from Mans-I were typically $<1.0 \mathrm{NTU}$ while those of other pump water samples were permanently $>1.0$ indicating acceptable and unacceptable drinking water qualities, respectively. In general, the highest turbidity values (44.5-49.5 NTU) were exclusively recorded for water samples collected from Talk-II pump (Tables 4-7).

Total dissolved salts (TDS) varied widely between $335 \mathrm{mg} \mathrm{L}^{-1}$ (Mans-I, winter, Table 4) and $12,423 \mathrm{mg} \mathrm{L}^{-1}$ (Talk-II, winter, Table 4). During this study, the water samples collected only from Mans-I and Mans-II can be regarded suitable for drinking as their TDS values were typically below $1000 \mathrm{mg} \mathrm{L}^{-1}$ while those collected from Mans-III, Talk-I, Talk-II and Talk-III were unsafe for drinking as TDS values were typically above the guideline limit (Tables 4-7). In general, the highest TDS values (typically above $10,000 \mathrm{mg} \mathrm{L}^{-1}$ ) were mainly reported for water samples collected from Talk-II pump.
Calculation of WQI integrates all the nine parameters (Tables 4-7) in a single value ranged between 0.0 and 100 (Table 2) denoting bad and excellent water quality, respectively. The lowest mean WQI (44.3, bad water quality) was recorded in summer for water sample collected from Talk-II pump (Table 6) while the highest one (94.2, Excellent water quality) was recorded in winter for Mans-I pump. Figure 2 illustrates the seasonal variations of WQI of different underground pump water samples collected during this study. It is clear that water samples collected from Mans-I pump maintained WQI values indicating good (70-90, in summer and autumn) and excellent (90-100, in winter and spring) quality conditions with obvious tendency towards the excellent border (Figure 2). WQI of water samples collected from Mans-II and Mans-III, Talk-I and Talk-III exhibited medium (50-70) water quality during all seasons. WQI values of Mans-II and Mans-III pumps were around 65, while those of Talk-I and Talk-III were around 55 indicating water qualities showing a tendency towards good and bad conditions, respectively. During this study, the worst bad water quality conditions were evident for all water samples collected from Talk-II pump, as values of WQI are remarkably below 50 , indicating bad water quality.

\subsection{Toxicity assessment of household pump water using standard algal growth bio-test}

It is evident from Table 8 that all water samples collected from Mans-I were nontoxic without any inhibitory effect on the growth of the test alga. However, water samples collected from other stations exhibited obvious toxic effects on growth of the test algae with varying degrees depending mainly of the sampled water and the sampling season. Values of $\mathrm{EC}_{50}$ fluctuated within a wide range between $15.8 \%$ (Talk-II, summer) and $83.1 \%$ (Talk-II, autumn). 
Table 4. Physical, chemical and bacteriological parameters of water quality index (WQI) of different six Abyssinian pumps distributed in Mansoura and Talkha cities during Winter season 2017. Data represent mean values of two readings of water samples collected in January 22, and Feburay 22, 2017.

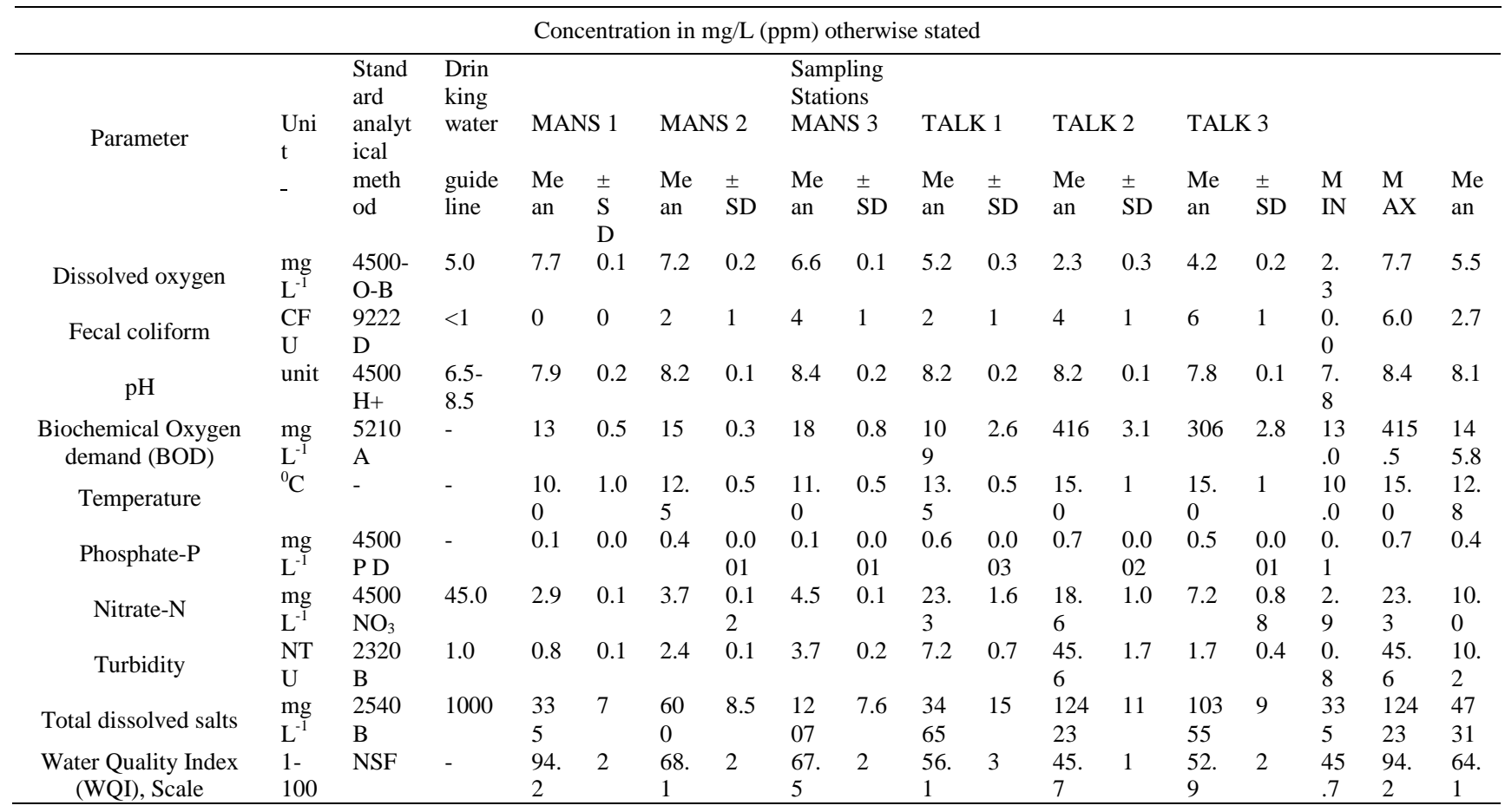

Table 5. Physical, chemical and bacteriological parameters of water quality index (WQI) of different six Abyssinian pumps distributed in Mansoura and Talkha cities during Spring season 2017. Data represent mean values of two readings of water samples collected in April 22, and May22, 2017.

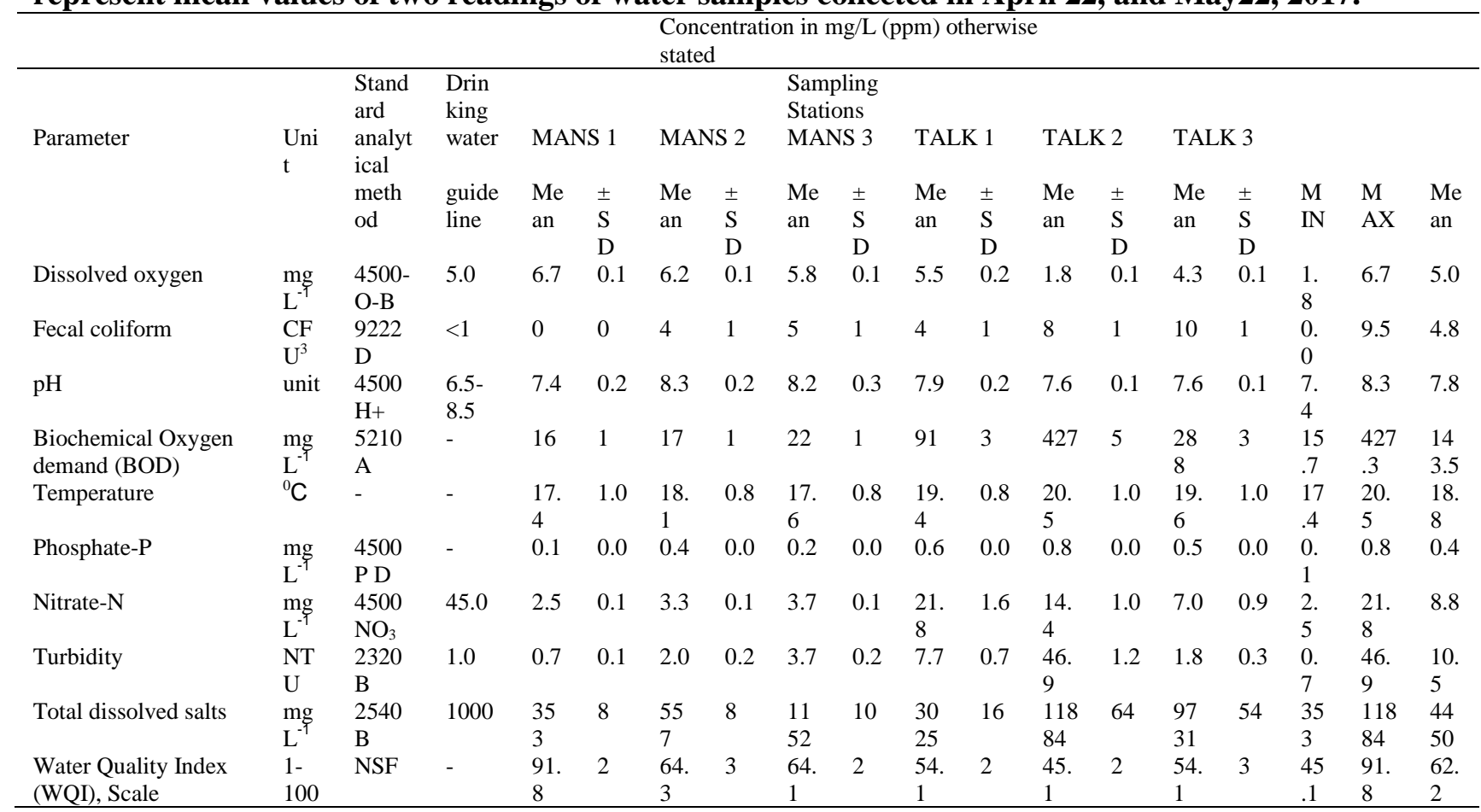


Table 6. Physical, chemical and bacteriological parameters of water quality index (WQI) of different six Abyssinian pumps distributed in Mansoura and Talkh cities during Summer season 2017. Data represent mean values of two readings of water samples collected in July 22, and August 22, 2017.

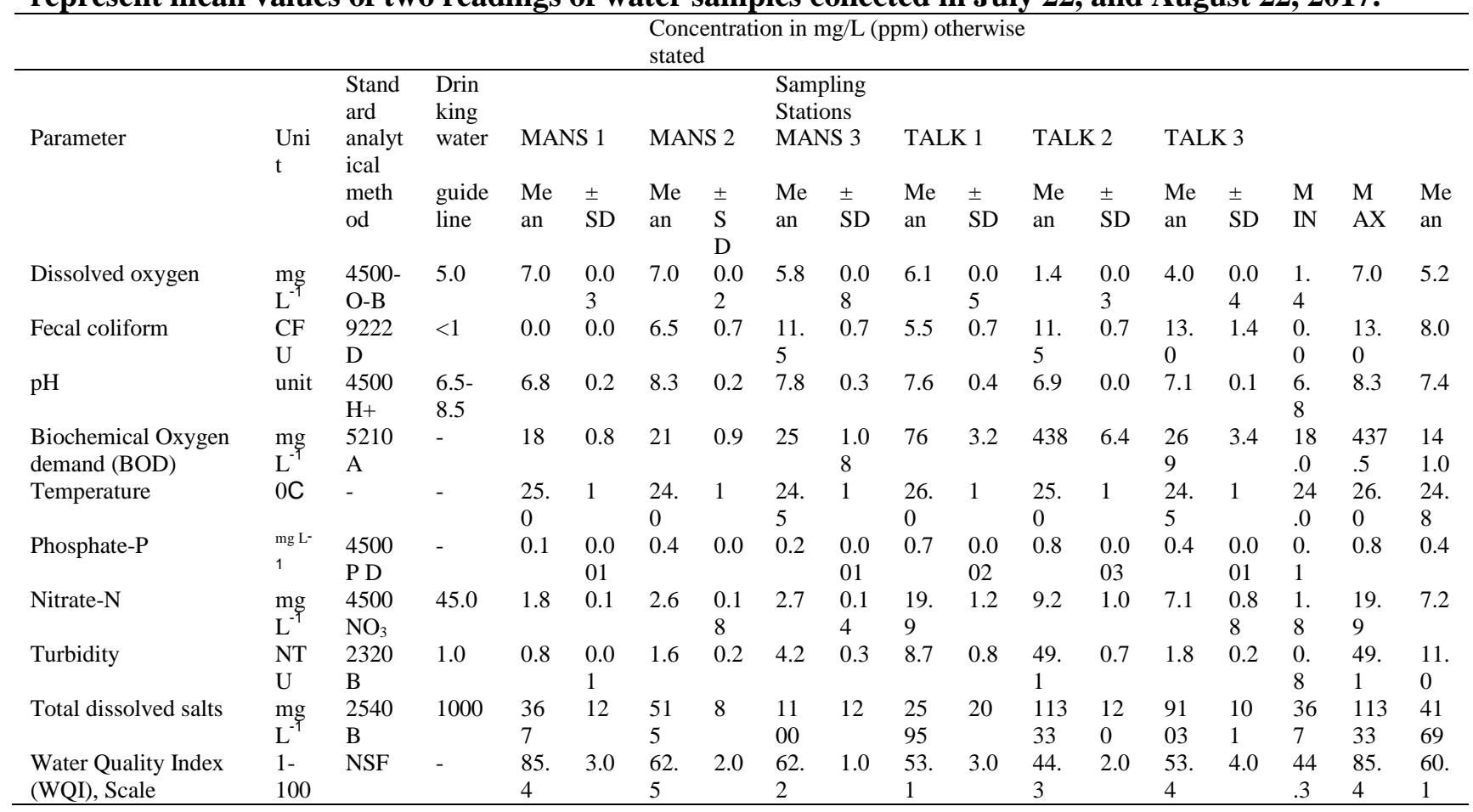

Table 7. Physical, chemical and bacteriological parameters of water quality index (WQI) of different six Abyssinian pumps distributed in Mansoura and Talkha cities during Autumn season 2017. Data represent mean values of two readings of water samples collected in October 22, and November 22, 2017.

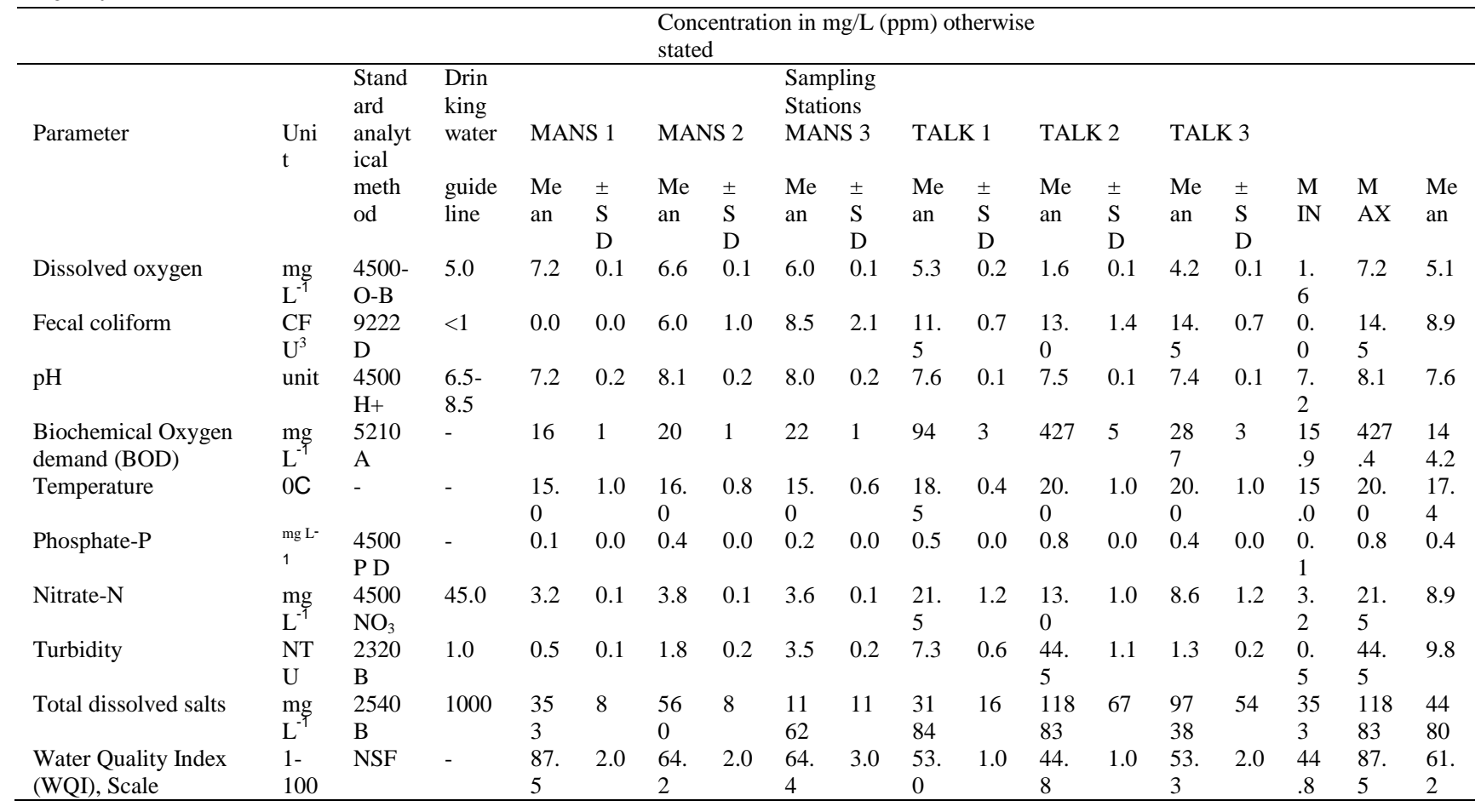




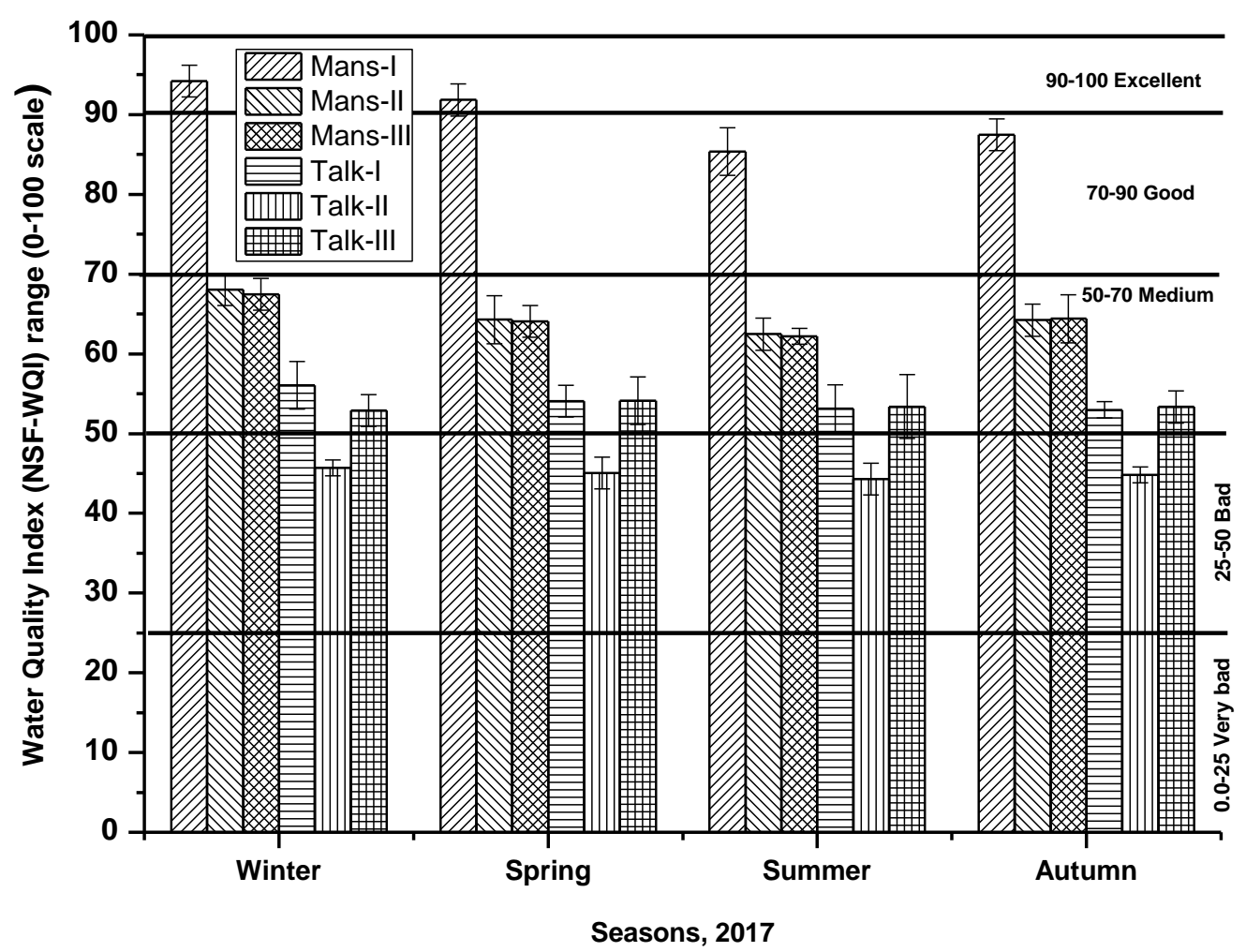

Figure 2. Seasonal variations in NSF-WQI of water samples collected from six Abyssinian pumps distributed in different villages of Mansoura and Talkha cities.

Table 8. Seasonal variations of $\mathrm{EC}_{50}$ of water samples collected from different pumps. Values represent the concentration of pump water $(v / v)$ inhibiting the algal growth by $50 \%$ compared to control.

\begin{tabular}{lllll} 
& \multicolumn{2}{c}{ EC $_{\mathbf{5 0}}$} \\
\cline { 2 - 5 } $\begin{array}{l}\text { Sampling } \\
\text { station }\end{array}$ & \multicolumn{4}{c}{ Seasons (2017) } \\
\cline { 2 - 5 } & Winter & Spring & Summer & Autumn \\
\hline Mans-I & NR & NR & NR & NR \\
Mans-II & 34.6 & 30.96 & 30.3 & 47.4 \\
Mans-III & 51.5 & 56.8 & 35.5 & 78.4 \\
Talk-I & 36 & 32.1 & 60.9 & 83.1 \\
Talk-II & 41.8 & 46.5 & 15.8 & 29.8 \\
Talk-III & 29.4 & 34.7 & 16.2 & 36.4 \\
\hline \multicolumn{5}{c}{ NR= Not recorded }
\end{tabular}

Although $\mathrm{EC}_{50}$ values express the toxicity of pump water in quantitative terms, it seems logic to compare the growth of the test algae in raw pump waters without any dilution with that of control culture (standard algal nutrient solution). In this connection, it seems important to highlight that the raw pump water was amended by $1.0 \mathrm{ml}$ from the different nutrient stock solutions of algal assay medium. This ensures that pump waters contain adequate concentrations of both macro- and micronutrients essential for the growth of the test algae and justifying the validly of growth comparison. The importance of this choice arose from the fact that pump water was used as it is without any dilution.

Figure 3 clearly illustrates seasonal variations of algal growth in pump waters compared to their corresponding culture controls. The term corresponding means a control patch, that was prepared in each season and kept under the same growth conditions of test cultures. This insures accuracy and validity of growth comparison between test and control cultures. This clearly manifest from Figure 3 as four bars of control cultures, corresponding to different seasons of collection, were included. It is obvious that only water samples collected from Mans-I pump did not impose any toxicity and/or inhibitory effects on growth of test alga. Compared to control cultures, the growth of the test alga in water samples collected from Mans-I, in all seasons, ranged between $95 \%$ and $106 \%$, indicating negligible growth inhibition and marginal growth stimulation, respectively (Figure 3) 


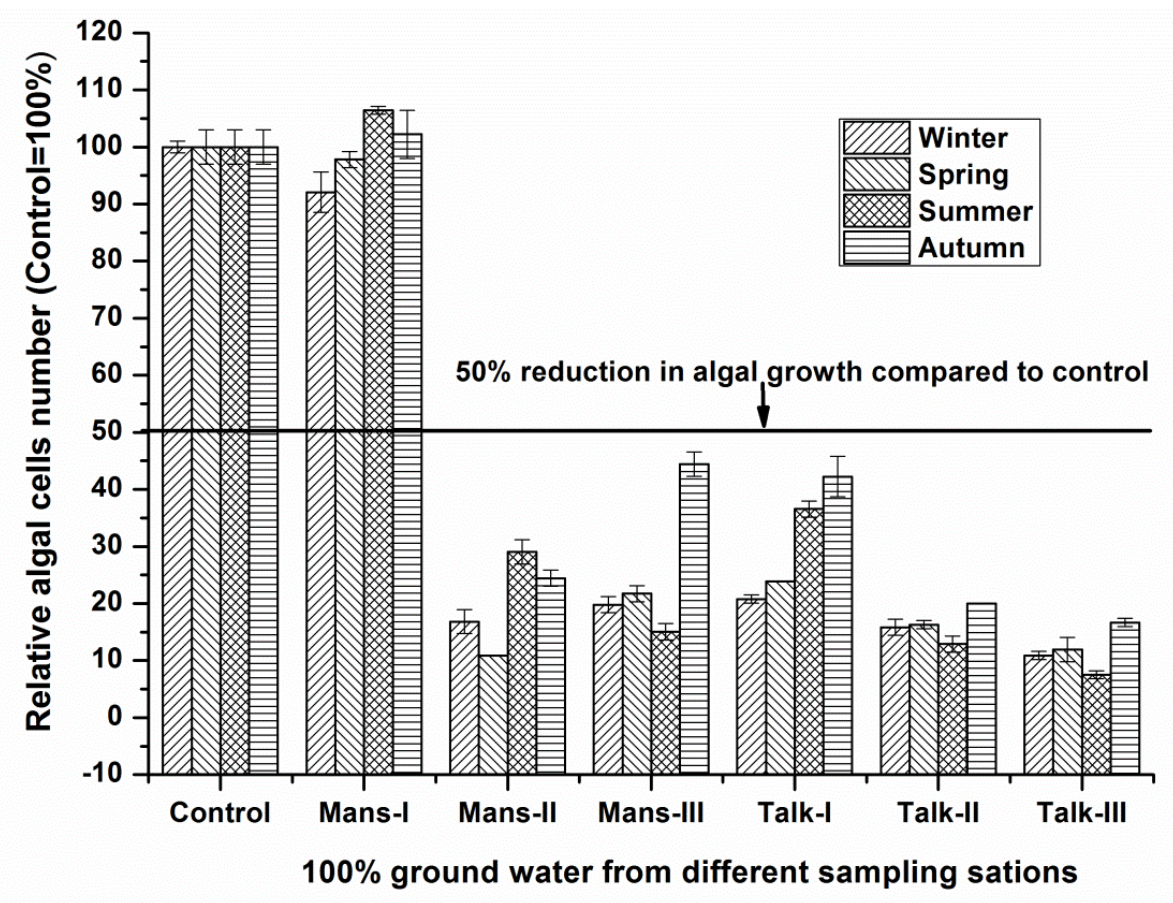

Figure 3. Growth of the alga Pseudokirchneriella subcapitata grown for three days in water samples collected from different six Abyssinian pumps. Bars represent the \% ratio between cell count of the tested raw water samples and control (standard algal nutrient solution) cultures (control=100\%).

On the other hand, the growth of the test algal in raw water samples taken from all other pumps in different seasons was significantly inhibited and obviously reduced by more than $50 \%$ compared to control crops (Figure 3). Growth inhibition of test algal was largely dependent on site and collection season.

\section{Discussion:}

According to the World Health Organization, up to $50 \%$ of developed countries' population suffers from health issues associated with lack of safe drinking water (1).In Egypt, nearly $56 \%$ of rural inhabitants are deprived of their right to a regular supply of municipal clean drinking water, and thereby they are exposed to detrimental health disorders such as renal failure, cancer, and high child mortality (1). For lack of other options, many Egyptians end up with drinking untreated underground water provided by hand (Abyssinian) pumps with a substantial chance of drawing polluted water (7).Accordingly, regular water quality monitoring and assessment of household Abyssinian pumps deserve ultimate importance for human health safety and welfare.In this study a host of water quality pertinent parameters including physico chemical characteristics, bacteriological, and growth responses of standard test alga were employed for integrated assessment of groundwater from different household Abyssinian pumps.

Water Quality index (WQI) represents a popular tool that has been extensively used for assessment of water quality all over the world. Calculation of WQI,this index, relies exclusively on nine parameters of crucial importance to assess health safety of water quality including DO, fecal coliform, $\mathrm{pH}$, BOD, temperature, phosphate-P, nitrate-N, turbidity and TDS (3). It seems important to briefly highlight the water quality relevance of different parameters upon which the calculation of WQI is based. Dissolved oxygen (DO) with concentration levels $\geq 5.0 \mathrm{mg} \mathrm{L}^{-1}$ is good to make drinking water taste better (18). The detection of $E$. coli in drinking water indicates fecal contamination that can pose serious health risk to consumers, particularly acute gastrointestinal illness (1). High levels of BOD may indicate fecal contamination or increases in particulate and dissolved organic carbon that can restrict water uses for domestic purposes (19). Being a vital macronutrient element, excess phosphate-P enhances proliferation of heterotrophic microorganisms, of underground water, including bacteria.High concentrations of nitrate-N cause infant methemoglobinemia that results in a decreased availability of oxygen to the vital organs and tissues (20). Turbidity describes the opacity of water caused by suspended matter, indicates thepresence of hazardous chemical and microbial contaminants, and maintains other significant implications on water quality (1).Total dissolved salts below $1000 \mathrm{mg} \mathrm{L}^{-1}$ is usually satisfactory to consumers. However, the presence of high levels of TDS in water may be unacceptable to consumers owing to the unacceptable taste and may 
also pose serious human illness depending on the chemical nature of the constituent dissolved salts (1). These facts highlight the ultimate importance of WQI and its parameters to assess public health and aesthetic qualities of water.

results in (Tables 6-9) indicated that only the water samples collected from the pump Mans-I, that located 50 meters away from the eastern (Damietta) branch of the River Nile, are health safe as drinking water. For instance fecal coliform bacteria were not recorded for any water samples collected throughout the whole period of the study. Values of other WQI parameters with drinking water guidelines including dissolved oxygen, $\mathrm{pH}$, nitrate- $\mathrm{N}$, turbidity, and total dissolved salts, are either coping perfectly or below the guidelines set for drinking water (16), the Water Quality Index (WQI) incorporates the values of different nine parameters to provide a single number that is easily interpretable and accurately indicates the overall water quality (Table 3 ) at a given location and time $(2,21)$.

WQI results (Figure 2 and Table 12) clearly indicate that water samples collected only from Mans-I pump maintained WQI values indicating either good or excellent quality conditions with obvious tendency towards the excellent border. WQI of water samples collected from Mans-II and Mans-III, Talk-I and Talk-III exhibited medium water quality conditions during all seasons. The worst water quality conditions were exclusively recorded for all water samples collected from TalkII pump, as values of WQI are remarkably below 50, indicating bad water quality (Figure 2). Accordingly, based on WQI only water samples collected from Mans-I pump are health safe for drinking purposes while water samples collected from other household Abyssinian pumps may pose serious human health disorders and illness.In a conclusion, WQI proved reliable approach to assess and to compare between drinking water qualities of underground pump water samples collected during this study and added a rigid support to similar previous water quality assessment studies (e.g., 22, 23)

Results of chemical analysis alone cannot estimate the health threat of underground pump waters. The use of bioassays is highly recommended (4). It has become clear that algae are self-evident research species to determine water quality.Although $\mathrm{EC}_{50}$ values (Table 8) express the toxicity of pump water in quantitative terms, it seems logic to compare the growth of the test algae in raw pump waters (Figure 3) without any dilution with the standard algal nutrient solution. The importance of this research decision arose from the fact that pump water was used as it is without any dilution. However, the tested pump waters must contain nutrients sufficient to the growth of the test algae during the test period. Therefore, adding of sufficient nutrients (7) to the tested pump water ensures that nutrients limitation of algal growth is unlikely to occur, sustains accuracy and validity of growth comparison between the test and control cultures, and indicate that growth inhibitory effects are mainly related to the overall toxicity of tested pump water. In this regard, Greene et al. (34) reported that in algal toxicity tests, confusing results may be obtained due to nutrient limitation.

The remarkable algal growth inhibition towards certain underground pump water samples (Figure 3) certainly indicates the presence of growth inhibitory and/or toxic ingredients, including, for instance, high levels of toxic heavy metals in addition to other growth hazardous ingredients as well. However, it must be mentioned that algal growth inhibition cannot be attributed to any single toxic component of the pump water, as the toxicity of any natural sample, including water, is the consequence of additive, antagonistic and synergistic interactions among all the constituents of that sample (5). Nevertheless, dramatic growth inhibition caused by the majority of underground water samples (Figure 3) may indicate their health unsafe quality to humans and domestic animals as well.The sensitive response of the standard test alga Pseudokirchneriella subcapitata to very narrow changes in quality of the tested solutions highlights the accuracy and importance of algal bioassays for water quality monitoring and toxicity assessment studies as recommend by the international standardizations organizations (4).

\section{Authors' declaration:}

- Conflicts of Interest: None.

- We hereby confirm that all the Figures and Tables in the manuscript are mine ours. Besides, the Figures and images, which are not mine ours, have been given the permission for republication attached with the manuscript.

- Ethical Clearance: The project was approved by the local ethical committee in University of Mansoura.

\section{References:}

1. Cotruvo JA. 2017 WHO guidelines for drinking water quality: first addendum to the fourth edition. $\mathrm{J}$ Am Water Works Assoc., 2017 Jul;109(7):44-51.

2. Kahler Royer CA. A water quality index devised for the Des Moines River in Central Iowa (Master's thesis, Iowa State University).

3. Akter T, Jhohura FT, Akter F, Chowdhury TR, Mistry SK, Dey D, Barua MK, Islam MA, Rahman 
M. Water Quality Index for measuring drinking water quality in rural Bangladesh: a cross-sectional study. JHPN. 2016 Dec;35(1):1-2.

4. [ISO] International Organization of Standardization. "Water quality-Freshwater algal growth inhibition test with unicellular green algae." (2012): 21.

5. Miller WE, Greene JC. The SelenastrumcapricornutumPrintz algal assay bottle test: Experimental design, application, and data interpretation protocol. Environmental Protection Agency, Office of Research and Development, Corvallis Environmental Research Laboratory; 1978.

6. Al-Hasawi ZM, Abdel-Hamid MI, Almutairi AW, Touliabah HE. Response of Pseudokirchneriellasubcapitata in Free and Alginate Immobilized Cells to Heavy Metals Toxicity. Molecules. 2020 Jan;25(12):2847.

7. Mohie El Din MO, Moussa AM. Water management in Egypt for facing the future challenges. J. Adv. Res.. 2016 May 1;7(3):403-12.

8. Loprieno N. International Agency for Research on Cancer (IARC) monographs on the evaluation of carcinogenic risk of chemicals to man:" Relevance of data on mutagenicity". Mutation research. 1975 Jun;31(3):210.

9. Hagras AE, El-Tantawy SA, El-NaggarAM, ElMakarm EA. Water Quality Index and Assessment of Heavy Metals in Two Groundwater Wells in Dakahlia Governorate, Egypt. GSJ. 2019 Mar;7(3).

10. Abdel-Shafy HI, Kamel AH. Groundwater in Egypt issue: resources, location, amount, contamination, protection, renewal, future overview. Egyptian. J. Chem. 2016 May 1;59(3):321-62..

11. Benediktsdóttir E, Gunnarsdóttir MJ, Ómarsdóttir BD, Sigurjónsson VÍ, Gardarsson SM. Virus inactivation in groundwater in a postglacial lava field in arctic climate. Lett. Appl. Microbiol. 2020 Apr;70(4):282-9.

12. El-Gammal MI, Ali RR, Samra RM. Assessing heavy metal pollution in soils of Damietta Governorate, Egypt. InInternational Conference on Advances in Agricultural, Biological \& Environmental Sciences, Dubai (UAE) 2014 Oct 15.

13. Megahed HA, Farrag AE. Groundwater potentiality and evaluation in the Egyptian Nile Valley: case study from Assiut Governorate using hydrochemical, bacteriological approach, and GIS techniques. Bull Natl Res Cent 2019 Dec 1;43(1):48.

14. Bradford SA, Harvey RW. Future research needs involving pathogens in groundwater. Hydrogeol J. 2017 Jun;25(4):931-8.

15. Rice A, Baird EW, Eaton RB. APHA 2017 Standard Methods for Examination of Water and Wastewater (Washington: American Public Health Association, American Water Works Association, and Water Env. Federation ISBN).

16. Organisationmondiale de la santé, WHO--Work programme, ŚwiatowaOrganizacjaZdrowia, World Health Organization, World Health Organisation Staff. Guidelines for drinking-water quality. World Health Organization; 2004 Aug 31.

17. Walsh GE, Deans CH, McLaughlin LL. Comparison of the EC50s of algal toxicity tests calculated by four methods.Enviro. Toxicol. Chem., 1987 Oct;6(10):767-70.

18. Javidi A, Pierce G. US households' perception of drinking water as unsafe and its consequences: Examining alternative choices to the tap. Water Resour. Res.. 2018 Sep;54(9):6100-13.

19. Abbasnia A, Yousefi N, Mahvi AH, Nabizadeh R, Radfard M, Yousefi M, Alimohammadi M. Evaluation of groundwater quality using water quality index and its suitability for assessing water for drinking and irrigation purposes: Case study of Sistan and Baluchistan province (Iran). Hum Ecol Risk Assess. 2019 May 19;25(4):988-1005.

20. Wagh VM, Panaskar DB, Mukate SV, Aamalawar ML, LaxmanSahu U. Nitrate associated health risks from groundwater of Kadava river basin Nashik, Maharashtra, India. Hum Ecol Risk Assess. 2020 Mar 15;26(3):654-72.

21. Alexakis DE. Meta-Evaluation of Water Quality Indices.Application into Groundwater Resources.Water. 2020 Jul;12(7):1890.

22. Wu Z, Wang X, Chen Y, Cai Y, Deng J. Assessing river water quality using water quality index in Lake Taihu Basin, China. Sci. Total Environ..2018 Jan 15;612:914-22.

23. Ustaoğlu F, Tepe Y, Taş B. Assessment of stream quality and health risk in a subtropical Turkey river system: A combined approach using statistical analysis and water quality index. Ecol. Indic. 2020 Jun 1;113:105815. 
تقييم جودة مياه الشرب لست مضخات حبثية باستخدام مؤشر جودة المياه واختبار الطحالب القياسي للسمية

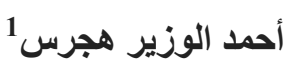

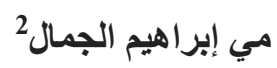

أحمد مصطفى النجار 1

مريم محمد اسماعيل 1

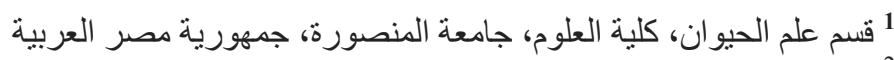

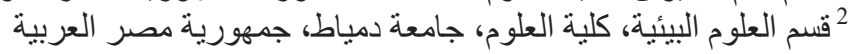

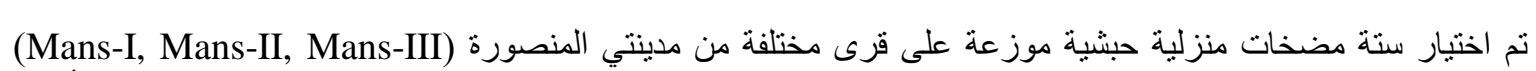

الخلاصة:

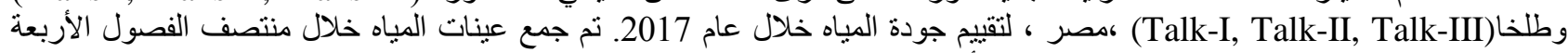

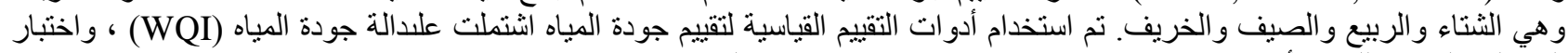

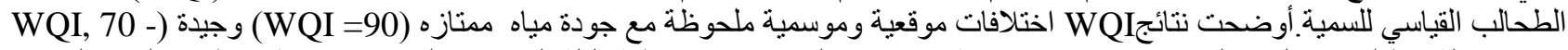

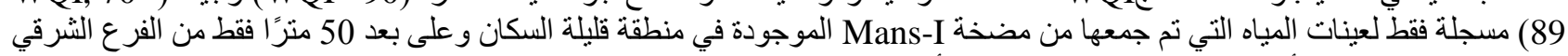

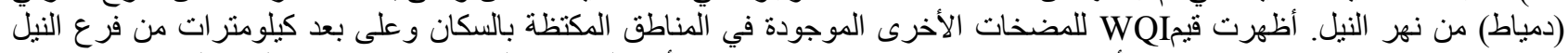

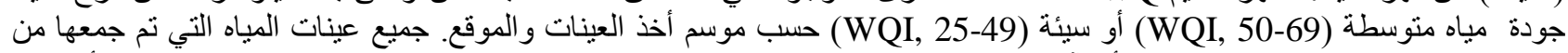

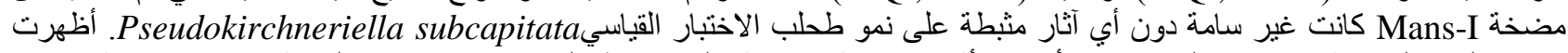

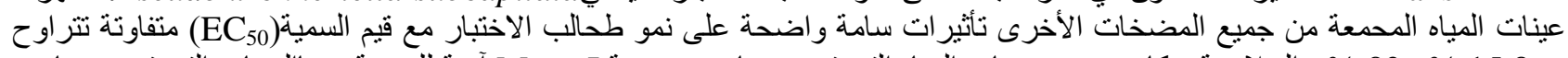

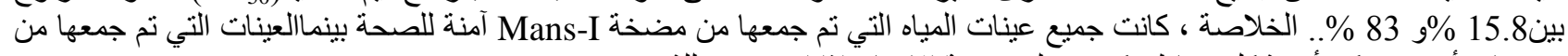
مضخات أخرى يمكن أن تشكل مخاطر كبيرة على صحة الإنسان إذا استخدمت للشرب. الكلمات المفتاحية: المضخات الحبشية، الاختبار ات الحيوية الطحلبية ، مياه الثرب ، مؤشر جودة المياه، أنبابيب أبار المياه الجوفية 